\title{
Problems of Ensuring Assistants' Support for Students with Functional Disorders in General Education Schools
}

\author{
*Judite Kulackovska, Regina Baltusite \\ Latvia University of Life Sciences and Technologies, Lielā street 2, Jelgava, LV - 3001, Latvia
}

\begin{abstract}
Children and students with functional disorders are one of the target groups of the inclusive education. Students with functional disorders can adapt in general education schools faster if their intellectual development is within the normal range. This group usually consists of disabled students, but they are able to master general education programmes successfully with an assistant's support. The purpose of the article is to explore the problems of assistants' support for students with functional disorders in general education schools. Adaptation of these students to general education schools would facilitate their development and enable them to undertake further studies not only in vocational education, but also in higher educational institutions. Assistant's support would promote the adaptation of these students to the class environment and ease the daily life of their parents. Having assessed the current situation, the authors conclude that the assistant's support will be effective if the assistant's functions and roles are recognized and if training of assistants for students with functional disorders in general education schools is ensured.
\end{abstract}

Key words: inclusive education, students with functional disorders, assistant, assistant's duties.

\section{Introduction}

25 years passed since the Salamanca Conference 1994, when serious attention was paid to the necessity of the inclusive education, and the concept of inclusion came into common use (UNESCO, 1994). Nevertheless, the issue of inclusion of children with functional disorders in general education schools is still topical. Since then, our society experienced certain changes in the attitude towards people who have some functional disorders. If we speak about the inclusive education, we have to separate the concepts of inclusion and integration, and this is one of the reasons why the implementation of the inclusive education has so many unanswered questions. According to the definition by UNESCO, inclusive education is a process where the respective needs of any student are ensured, thus increasing the possibilities to get involved in the process of studies, culture and various societies for everyone (Daniela \& Varkals, 2013). Inclusive education is to be implemented starting with the moment when a child is born (Казанцева \& Биляченко, 2017). Inclusive education reduces the possibilities of excluding students with functional disorders from the process of acquiring education. The role of inclusive education is highlighted in various levels documents and regulatory enactments of the world (UNESCO1994, 2015; United Nations, 2011, 2015), Europe (Eiropas speciālās izglîtības aǵentūra, 2009; Iekḷaujošās izglītības manifests. Kas būtu nekavējoties jādara?, 2012; UNESCO, 2018) and Latvia (LR Saeima, 1999, 2011; Kārtība, kādā pieškiir un finansē asistenta pakalpojumu izglītîbas iestādē, 2012). Despite the fact that we have made a good progress in other aspects of the inclusive education, the role of the assistant in the implementation of inclusive education in general education schools so far has been little studied in the researches by Latvian pedagogy and psychology scientists. Four promotional papers have been defended in the inclusive education (Bērzina, 2010; Guseva, 2012; Nīmante, 2008; Rozenfelde, 2016) (Nìmante, 2018), but the role of assistant in general education schools has not been studied in the researches by Latvian pedagogy scientists. At the same time, the research by The State Audit Office (LR Valsts kontrole, 2015) established that the assistants' services in education institutions is not the most efficient support service contributing to the inclusion

\footnotetext{
* Corresponding Author's email: judite.kulackovska@inbox.lv
} 
of the functionally impaired students in general education schools.

\section{Materials and Methods}

The purpose of the article is to explore the problems of assistants' support for students with functional disorders in general education schools. In order to assess the assistant's role in the implementation of inclusive education, the authors of the article chose the methods as follows: 1) the analysis of theoretical insights and regulatory documents; 2) reflection of personal experience of the authors acquired during their professional activity (social worker, psychologist); 3) analysis of the statistical data related to the researched target groups.

\section{Results and Discussion}

The problem of inclusive education is highly topical nowadays, as the number of children and adults with special needs increases not only in Latvia, but also in other states of the world. The Global Education Meeting that took place in Brussels in December 2018 introduced the implementation of the 2030 Agenda for Sustainable Development 4 Goal to ensure inclusive and equitable quality education and promote life-long learning opportunities for all (UNESCO, 2018). An important attribute of the information society is aiming at universal human values, that is, integration of science, culture and education (Пашкова \& Скуднова, 2018). The concept of inclusive education is characterised by (Пашкова \& Скуднова, 2018): a) equal rights to the appropriate comprehensive development, communication and education for all children; psychological pedagogical support; b) joint studying and upbringing of children with and without functional disorders; c) catering to the needs for support and friendly attitude of the peer. Implementing the inclusive education, the concepts of integration and inclusion should be distinguished.

Gradual transition from the integration concept to the inclusive education concept can be depicted as follows (Table 1).
Rather than adapting students to the defined requirements, inclusive education involves changing the school activity and searching for new pedagogical approaches in educating of students with special needs (Iekḷaujošās izglītības manifests. Kas būtu nekavējoties jādara?, 2012; Loreman, Deppeler \& Harvey, 2005; Rozenfelde, 2018; UNESCO, 2015; Казанцева \& Биляченко, 2017; Пашкова \& Скуднова, 2018).

We will proceed with the characterisation of functional disorders, which should be included in the general education schools.

The Education law defines that a child with special needs is "a child requiring additional medical, pedagogical and social assistance due to some dysfunctions of internal organs' systems caused by disease, trauma or congenital defect, regardless of whether disability has or has not been assigned". The Law on Social Services and Social Assistance defines the term of functional disorder as a disorder of a physical or mental nature caused by a disease, trauma or congenital defect which restricts the ability of a person to work, take care of himself or herself and makes it difficult for the person to integrate into society (LR Saeima, 2003). Functional limitation a disorder of human body functions, activities and involvement caused by a disease, trauma or congenital defect (VDEĀVK (Guidelines for the Evaluation of a Person's Health, Functional Capacity and General Working Capacities), 2013). The distinction is made between (Waddington \& Diller, 2002): a) medical model; b) social model, which characterises any loss of health as a disadvantage or exclusion and which can be improved by the appropriate health care and social care politics and the financial support system. Social policy documents applicable in Europe are mainly based on this social welfare model and therefore they are based on the medical definition of disability (VDEĀVK, 2013). According to the World Report on Disability, the disability should be perceived as a normal part of anyone's life (Pasaules veselības organizācija, 2003). This is a so-called "bio-psychosocial model of disability". Impotence

Table 1

The transition from the integration concept to the inclusive education concept (according to Пашкова\&Скуднова, 2018)

\begin{tabular}{|l|l|l|l|}
\hline Regular education & Special education & Integrated education & Inclusive education \\
\hline Regular child & Special needs child & The system remains the same. & All children are different. \\
\hline Regular teachers & Special teachers & $\begin{array}{l}\text { A child either adapts to the } \\
\text { system or becomes unacceptable } \\
\text { for it. }\end{array}$ & $\begin{array}{l}\text { Similar rights for all } \\
\text { children. }\end{array}$ \\
\cline { 1 - 3 } Regular schools & Special schools & \begin{tabular}{l}
$\mid$ \\
\hline
\end{tabular}
\end{tabular}


or disability is the general concept that involves worsening of condition, limitation of activities and movements, limitation of involvement and negative aspects of correlation between a person's health condition and his contextual factors. Currently in Latvia, a doctor's opinion is the most important diagnostics aspect for the following functional disorders - vision, hearing disorders, physical and somatic diseases. Table 2 describes the types of functional disorders summarized according to various sources of information (movement disorder Архипова, 2017; Особенности обучения ребенка с нарушениями опорно-двигательного аппарата в общеобразовательном учреждении, 2012; hearing disorders - Umbraško, 2016; vision disorders -
Виды нарушений зрения у детей, 2016; somatic disorders - Neo, Kukreja, 2019).

In the implementation of inclusive education, it is important to use the insights of psychology, which would help in organising the study process, professional development of teachers, classification of students etc. (Hick, Kershner, \& Farrell, 2009). A methodology of the development assessment criteria and individual evaluation of children with functional disorders was elaborated in Latvia in 2016 (Bērna ar funkcionāliem traucējumiem attīstības vērtēšanas kritēriju un individuālā izvērtējuma metodika, 2016). The assessment of a child's development includes 4 spheres: 1) physical development (refers to child's abilities to act by using his movements, including the

Types of functional disorders (Authors' design)

Table 2

\begin{tabular}{|c|c|c|}
\hline $\begin{array}{l}\text { Functional } \\
\text { disorders }\end{array}$ & Distinctive features & $\begin{array}{l}\text { Schools where they } \\
\text { study }\end{array}$ \\
\hline $\begin{array}{l}\text { Movement } \\
\text { disorders }\end{array}$ & $\begin{array}{l}\text { Movement disorders can be caused by: 1) congenital disorders; } \\
\text { 2) congenital pathologies of the locomotor system; 3) acquired diseases } \\
\text { and damages of the locomotor system - traumatic injury of brain, } \\
\text { spinal cord. Types of movement disorders - infantile cerebral paralysis; } \\
\text { poliomyelitis. }\end{array}$ & $\begin{array}{l}\text { Latvian schools } \\
\text { with the respective } \\
\text { educational code }\end{array}$ \\
\hline $\begin{array}{l}\text { Visual } \\
\text { disorders }\end{array}$ & $\begin{array}{l}\text { 1. Nearsightedness or myopia - light rays focus in front of the retina, as } \\
\text { a result the objects appear blurry. } \\
\text { 2. Farsightedness is an anomaly of the eye refraction, when parallel } \\
\text { rays after refraction in the eye optical system are transferred to the } \\
\text { retina in a converging state but not yet crossed in one point - focus. } \\
\text { 3. Strabismus is a lack of coordination between the eyes, which causes } \\
\text { the loss of binocular vision. } \\
\text { 4. Astigmatisms is a visual disorder, blurry near or far vision, however, } \\
\text { the problem is usually more often experienced with far vision. } \\
\text { 5. Amblyopia (lazy eyes) - decrement of visual acuity in one or both } \\
\text { eyes, which cannot be corrected neither with glasses, nor with contact } \\
\text { lenses and which is connected with structural changes in the eye. }\end{array}$ & $\begin{array}{l}\text { Stradzumuiza } \\
\text { Secondary } \\
\text { Boarding School }\end{array}$ \\
\hline $\begin{array}{l}\text { Hearing } \\
\text { disorders }\end{array}$ & $\begin{array}{l}\text { Three types of hearing disorders are mentioned: 1) conductive - reduced } \\
\text { ability to hear sounds or faint and soft sounds; 2) neurosensory - damages } \\
\text { in the inner ear (Cochlea) or in the nerves tract from the inner ear up to the } \\
\text { brain, this kind of disorders are incurable; } 3 \text { ) mixed damages of both the } \\
\text { external and/or middle portion of the ear and of the inner ear. The degrees } \\
\text { of severity are distinguished as follows: a) mild hearing loss; b) moderate } \\
\text { hearing loss; c) severe hearing loss and deafness. }\end{array}$ & $\begin{array}{l}\text { Riga city } \\
\text { secondary boarding } \\
\text { school, Valmiera } \\
\text { city secondary } \\
\text { boarding school - } \\
\text { development centre }\end{array}$ \\
\hline $\begin{array}{l}\text { Somatic } \\
\text { symptom } \\
\text { disorders }\end{array}$ & $\begin{array}{l}\text { According to the main medicine concept, a human being is one } \\
\text { integral organism, which should be cured as one whole. It is based on a } \\
\text { biopsychosocial model of health and illness, which defines that the origin } \\
\text { of various psychosomatic disorders and diseases is affected by } 3 \text { factors: } \\
\text { biological (innateness, physical and chemical irritants, microorganisms } \\
\text { etc.); mental (personality, mood, emotions etc.); social (relationships at } \\
\text { work, home, life changes etc.). }\end{array}$ & $\begin{array}{l}\text { In Latvian schools } \\
\text { with the respective } \\
\text { educational code }\end{array}$ \\
\hline
\end{tabular}


activities of daily living); 2) intellectual development (refers to child's abilities to understand, think, remember information and the ability to make and use reasoning); 3 ) social skills (refer to a child's ability to cooperate with others (peer and adults) in home environment and outside of it); 4) behaviour (refers to a child's abilities to act and express himself). Each sphere consists of a mixture of certain criteria and markers.

The markers are measured according to a 4-point evaluation system: a) not applicable in the assessment of the child $(n / a) ; \mathrm{b})$ demonstrates a pronounced developmental delay considering the child's age (1); c) demonstrates a partial developmental delay considering the child's age (2); d) demonstrates the development corresponding to the child's age (3); e) demonstrates the development exceeding the average markers of the child's age (4). A pronounced developmental delay means a child is not functioning in accordance with his age in certain spheres, including the respective sphere, and demonstrates serious delay in the development of physical, mental, behavioural and social skills. If the average level of markers is 1.0-1.9 in all or almost all spheres, emergency support must be ensured to such a child. A partial developmental delay means a child demonstrates a delay in the development of some physical, mental, behavioural and social skills. If the average level of markers in these spheres of development is 2.02.9 , it means that the child needs a specific support. Development corresponding to the child's age means that the child is functioning in accordance with the average markers of physical, mental, behavioural and social skills development relevant for his age group. If the average level of markers in these spheres is 3.03.9, the child does not need any support in his physical and mental development. Development exceeding the average markers of the age in physical, mental, behavioural and social spheres is the optimal level. If the average level of markers is 4.0, it demonstrates that the child is properly functioning and means that the child exceeds the average markers of development relevant for his age. The assessment of children and students is performed by such specialists as a special teacher, logopedist, psychologist, physiologist, social counsellor. The application of the elaborated methodology will allow for an unbiased examination and characterisation of the group, which will further contribute to rendering support to children and students with functional disorders in general education schools.

The support system for the implementation of the inclusive education includes (Rozenfelde, 2018): 1) state-organised and state-funded support system; 2) municipality-organised and municipality-funded support system; 3) educational institution system. Having examined Latvian educational institutions, it can be concluded that a number of education programmes, also including the programmes for students with functional disorders, is licensed in small regional schools, which in this way slightly increase the number of students and create a possibility for students to join a general education school closer to their place of residence. To enable the students with functional disorders adapt to the environment of a general education school, they should be supported by assistants of the respective competence. The essence of the assistant's services, as well as the assistant's role and functions follow from the term defined in the Disability Law (LR Valsts kontrole, 2015): “An assistant - a natural person, who gives assistance to a person with a very severe or severe level of limited functioning in performing such activities outside his or her dwelling, which due to his or her disability cannot be performed independently, - to get to the place where he or she is studying, working, receiving services; to move about and to take care of himself or herself in an educational institution". The same person can give assistance in an educational institution as defined by municipality and the Disability Law. The service can be rendered by a natural person who has a working or personal experience in taking care of people with disability or the respective education, or a work experience in the sphere of pedagogy, psychology, medicine, healthcare and social work.

The total number of disabled children in Latvia is about eight thousand (Krieviňš, 2018). Among them, special care is required for 2000 children. These children qualify for assistants' services. However, only one eighth of these children have assistants their number varies from 250 to 290 during recent years (Table 3). In accordance with Table 3, the number of students in Latvia who need assistants' services is increasing each year, and, considering changes initiated in the sphere of education, engaging of assistants will become more and more topical.

Table 3

The number of people receiving state-funded assistants' services (according to LR Valsts kontrole, 2015)

\begin{tabular}{|l|c|c|c|}
\hline Indicators & 2013 & 2014 & 2015 \\
\hline $\begin{array}{l}\text { Number of students } \\
\text { receiving the service }\end{array}$ & 214 & 245 & 290 \\
\hline Funding used, EUR & 271908 & 490685 & 626572 \\
\hline
\end{tabular}


Pros and cons of having family members as assistants (according to LR Valsts kontrole, 2015)

Table 4

\begin{tabular}{|c|c|c|}
\hline $\begin{array}{l}\text { Involved } \\
\text { party }\end{array}$ & Advantages & Disadvantages \\
\hline $\begin{array}{l}\text { A person } \\
\text { with } \\
\text { disability }\end{array}$ & $\begin{array}{l}\text { A recipient of services feels safer, as a } \\
\text { family member has stronger affection } \\
\text { to the assisted person; a possibility to } \\
\text { receive services during longer hours than } \\
\text { defined; a possibility to make unforeseen } \\
\text { changes in the time schedule; a possibility } \\
\text { to replenish family budget; the service } \\
\text { provider is officially employed. }\end{array}$ & $\begin{array}{l}\text { The service provider is under a constant } \\
\text { control; daily routine is subordinated } \\
\text { to the assistant's needs; the feeling of } \\
\text { dependence and guilt, as well as emotional } \\
\text { and/or physical violence; social skills } \\
\text { are not promoted, which could require a } \\
\text { more complicated approach and services } \\
\text { in future if a family member will not be } \\
\text { able to give assistance any more. }\end{array}$ \\
\hline $\begin{array}{l}\text { Assistant } \\
\text { (family } \\
\text { member) }\end{array}$ & $\begin{array}{l}\text { A possibility to control the relative; a } \\
\text { possibility to use additional formal and } \\
\text { non-formal benefits given by the society } \\
\text { to disabled persons; a possibility to feel } \\
\text { indispensable; a possibility to replenish } \\
\text { family budget. }\end{array}$ & $\begin{array}{l}\text { The service provider is exposed to } \\
\text { possible mental and physical overstrain; } \\
\text { impossibility of personal life, feeling of } \\
\text { guilt; loss of professional skills, career } \\
\text { growth. }\end{array}$ \\
\hline $\begin{array}{l}\text { Funder } \\
\text { (the state) }\end{array}$ & $\begin{array}{l}\text { Less responsibility for the quality of } \\
\text { services; rendering of services does not } \\
\text { directly depend on the amount of funding, } \\
\text { the process of choosing an assistant } \\
\text { and administration of services can be } \\
\text { simplified. }\end{array}$ & $\begin{array}{l}\text { A risk that the service will not reach } \\
\text { its aim; difficult to control the service } \\
\text { quality. }\end{array}$ \\
\hline
\end{tabular}

Still not all parents use the assistant's service, or such services are provided by a family member, but the assistant's services cannot be properly performed if combined with other work duties.

A state-funded assistant's services in an educational institution include the assistance in the following activities (Kārtība, kādā pieškiir un finansē asistenta pakalpojumu izglītības iestādē, 2012): moving about in educational institution; performing self-care (for example, personal hygiene, assistance in eating, dressing and undressing, clothes sorting); communication with teachers; making study notes and preparation of study materials for working with them; arrangement of study accessories and place of studies; communication with peer and other people in the educational institution (for example, during the brakes and extended day groups, extracurricular activities etc.); participation in the events organised in the educational institution, and other services. The authors' personal experience shows that the assistant's duties are often performed by family members, who have no proper experience, but the money received for the services remains in the family budget. It reduces the possibilities of support for its recipient. With reference to the results of international researches and the experience of other European countries, the report of a Revision Committee is also pointing at practical and emotional benefits and drawbacks from a recipient's, assistant's and funder's perspective (LR Valsts kontrole, 2015) (Table 4).

Further on, it is advisable to limit rendering of services by family members, except for individual difficult cases. A number of international researches clearly define that hiring a family member as an assistant can cause and often causes mutual dependence (European Network on Independent Living, 2013). A mother (or parents) is not able to give up her duty to care for her disabled child, she thinks it is the mission of her life and rejects categorically a possibility that someone else, except for her, could be able to ensure proper care for her child. To avoid this situation, legislation of many states is deliberately elaborated in such a way to prevent or reduce the risk of occurrence of such dependence. It has been established that every third assistant is an educational institution employee who performs the assistant's duties in addition to his direct work duties (LR Valsts kontrole, 2015). It happens 
because there are no certain competencies, functions and roles defined for assistants. The assistant's functions and duties during a class are not the same as the functions and duties of a teacher's assistant. This is where a conflict appears between the support rendered to students during a class by the pedagogical staff and by the assistant.

In inclusive education, the assistant can be a longterm strategy viewed as a systematic approach to the educational environment of the school focused on the aim in general, rather than just a local problem (Староверова, Ковалев, \& Захарова, 2018). Therefore, inclusive education is possible if schools change their way of thinking; if attitude changes and the system of teachers' work is arranged in a way that would promote the inclusion of every student (Iekḷaujošās izglīīības manifests. Kas būtu nekavējoties jādara?, 2012; Loreman, Deppeler, \& Harvey, 2005; Pētījums par bērniem ar speciālām vajadzībām sniedzamo atbalsta pakalpojumu izmaksu modeli iekḷaujošas izglîtīibas īstenošanas kontekstā, 2017; Rozenfelde, 2018; VISC, 2017; Пашкова \& Скуднова, 2018). Inclusive education affects all the stakeholders - children with functional disorders, their parents, classmates, teachers and everyone involved in the process of studies - administration and other subordinated structures. Its aim is to ensure high quality education for students closer to their place of residence. In order to achieve the maximum possible inclusion, alliances must be defined and persons responsible for a respective student must be established (Voitkane, 2017). Therefore, the assistant's support for students with functional disorders is very important, but we need to train assistants so that they could perform their duties in a general education school efficiently. Considering that the number of children who need assistants is rather big, we should think about assistants as a profession standard, because as it follows from the sources of information that have been considered, the support team plays an important role in delivering support to students with functional disorders, and at the same time there is currently a big mess in this sphere. It can be based on the professional standard for assistants giving support to persons with hearing disorders (VISC, 2010), as well as on the list of values, knowledge and skills elaborated for companions - assistants for people with functional disorders within a cross-border project (Pavadonis - asistents cilvēkiem ar funkcionāliem traucējumiem. Pakalpojuma koncepcija, 2013).

\section{Conclusion}

Implementation of inclusive education and its culture is possible subject to changing attitude of the society towards the people with special needs.
Important role within the context of inclusive education belongs to the work of a support team, including assistants, whose services in Latvia are described in the Disability Law. Despite of this, when we speak about a support team, we do not speak about assistants.

In order to optimize the assistants' support for students with functional disorders in general education schools, it is necessary: a) to define professional competencies of assistants, their functions and roles, as at the moment they are described in very general terms; b) to organise training of assistants giving support for students with functional disorders in general education schools, as assistants have to know specific psychological features of such students; c) to establish the profession of an assistant and to elaborate the standard of the profession of an assistant giving support for students with functional disorders in general education schools.

\section{References}

1. Bērna ar funkcionāliem traucējumiem attīstības vērtēšanas kritēriju un individuālā izvērtējuma metodika (Criteria of Assessment of Children with Functional Disabilities and Methodology of Individual Assessment) (2016, March). Retrieved February 5, 2019, from http:// www.lm.gov.lv/upload/aktualitates/6/bernu metodika_ft_gala_1304.pdf( In Latvian)

2. Daniela, L., \& Varkals, J. (2013, April). Visiem bērniem vienādas ties̄̄bas. Vai tiešām visiem? (Equal Rights for All Children. Is it Really for All?). Retrieved November 2, 2018, from http:// providus.lv/en/articles/8078/print (In Latvian)

3. Eiropas speciālās izglītības aǵentūra (2009). Galvenie principi kvalitātes veicināšanai ieklaujošā izglītībā. Rekomendācijas politikas veidotājiem (Key Principles for Promoting Quality in Inclusive Education: Recommendations for Policy Makers). Retrieved November 3, 2018, from https://www.europeanagency.org/sites/default/files/key-principles-forpromoting-quality-in-inclusive-education_keyprinciples-LV.pdf (In Latvian)

4. European Network on Independent Living (2013, February). Personal Assistant Services in Europe. European Survey: Ireland. Retrieved October 13, 2018, from http://www.enil.eu/wpcontent/uploads/2013/02/European-Survey-onPersonal-Assistance-Final.pdpp 17

5. Hick, P., Kershner, R.,\& Farrell, P. (2009). Psychology for Inclusive Education: New Directions in Theory and Practice. London and New York: Routledge - Palmer. 
6. Iekḷaujošās izglītības manifests. Kas būtu nekavējoties jādara? (Manifesto on Inclusive Education. What Should Be Done Immediately?) (2012, September). Retrieved December 14, 2018, from http://www.lkndz.lv/lv/box/files/ filelists/1388669901-budapestasmanifests.pdf (In Latvian)

7. Kārtība, kādā piešķir un finansē asistenta pakalpojumu izglītības iestādēe (The Procedure for Provision and Funding of Assistants' Services in Educational Institutions) (2012, September). MK noteikumi Nr. 695. Retrieved September 4, 2018, from https://ikumi.lv/doc. php?id=252140 (In Latvian)

8. Krievinšs, R. (2018). Asistentu skaits skolēniem ar invaliditāti ik gadu nemain̄̄gs; praksi plāno ieviest arī augstskolā (The Number of Assistants for Disabled Students Remains the Same Throughout Years; the Practice is also Planned to be Implemented in Higher EducationIinstitutions). Retrieved September 29, 2018, from https://www.lsm.lv/raksts/ zinas/latvija/asistentu-skaits-skoleniem-arinvaliditati-ik-gadu-nemainigs-praksi-planoieviest-ari-augstskolas.a292636/ (In Latvian)

9. Loreman, T., Deppeler, J., \& Harvey, D. (2005). Inclusive Education: A Practical Guide to Supporting Diversity in the Classroom. London and New York: Routledge - Palmer.

10. LR Saeima (1999, June). Izglīitîas likums (Education Law) (1998). Retrieved September 4, 2018, from https://likumi.lv/doc.php?id=50759 (in Latvian)

11. LR Saeima (2003, January). Sociālo pakalpojumu un sociālās palīdzības likums (The Law on Social Services and Social Assistance). Retrieved February 23, 2019, from https:// likumi.lv/doc.php?id=68488 (In Latvian)

12. LR Saeima (2011, January). Invaliditātes likums (Disability Law). Retrieved September 4, 2018, from https://likumi.lv/doc.php?id=211494 (in Latvian)

13. LR Valsts kontrole (2015, February). Vai personām ar invaliditāti paredzètais asistenta pakalpojums nodrošina tā izveidošanas mērķu sasniegšanu? (Does the Services of the Assistants for Disabled Persons Ensure the Implementation of the Intended Goals?). Retrieved February 1, 2019, from http://www.lrvk.gov.lv/uploads/ reviziju-zinojumi/2015/2.4.1-10_2015/20.p_ revizijas-zinojums_asistenti_lm.pdf (In Latvian)

14. Neo, P. \& Kukreja, K. (2019, February). Psychosomatic Disorder: Causes, Symptoms, Types, And Treatments. Retrieved February 2, 2019, from https://www.stylecraze.com/articles/ psychosomatic-disorder-causes-symptomstreatments/\#gref

15. Nīmante, D. (2018). Zinātniski pētnieciskās aktivitātes par ieklıujošo izglītību Latvijas augstskolās (Research Activities on Inclusive Education in Latvian Higher Education Institution). Rīga: LU (In Latvian)

16. Pavadonis - asistents cilvēkiem ar funkcionāliem traucējumiem. Pakalpojuma koncepcija (Companion - an Assistant for Disabled People. Service Concept) (2013). Siauliai. Retrieved February 23, 2019, from http://www. edupro.1t/images/latlit/concept/LLIV-322\%20 Companion $\% 20$ asistant $\% 20$ concept $\% 20$ LV.pdf (In Latvian)

17. Pètījums par bērniem ar speciālām vajadzībām sniedzamo atbalsta pakalpojumu izmaksu modeli iekl̦aujošas izglītības īstenošanas kontekstā (Research on the Model of Expenses of Support Services Rendered to Children with Special Needs within the Context of the Implementation of Inclusive Education) (2017, December). Autoru kolektīvs. Rīga:LU. Retrieved February 28, 2019, from https://www.izm.gov.lv/images/izglitiba_ visp/IZMiepirkumamLUPPMFgalaparskats 08122017.pdf (In Latvian)

18. Rozenfelde, M. (2018). Skolēnu ar speciālajām vajadzībām iekļaušanas vispārējās izglītības iestādēs atbalsta sistēma (The Support System for the Inclusion of Students with Special Needs in General Education Institutions). Rēzekne: Rēzeknes Tehnologiju akadēmija. (In Latvian)

19. Pasaules veselības organizācija (2003). Starptautiskāa funkcionēšanas, nespējas un veselības klasifikācija (International Classification of Functioning, Disability and Health). Retrieved February 23, 2019, from https://apps.who.int/iris/bitstream/ handle/10665/42407/9241545429 lav.pdf (In Latvian)

20. UmbraškoS.(2016, November). Intelekta saistība ar zīmju valodas un lasī̌sanas prasmi bērniem ar dzirdes traucējumiem (The Relationships among Intelligence, Sign Language comprehension and Reading Skills in Deaf and Hearing impaired Children). Promocijas darbs. Rīga: LU. Retrieved February 5, 2019, from https://dspace. lu.lv/dspace/bitstream/handle/7/34451/29856209-Umbrasko_Solvita_sp11072.pdf? (In Latvian)

21. UNESCO (1994, June). The Salamanca Statement and Framework for Action on Special Needs Education. Retrieved February 23, 2019, from: http://www.unesco.org/education/pdf/ SALAMA_E.PDF 
22. UNESCO (2015, May). Education 2030 Framework for Action. Retrieved February 5, 2019, from http://uis.unesco.org/sites/default/ files/documents/education-2030-incheonframework-for-action-implementation-of-sdg42016-en_2.pdf

23. UNESCO (2018, December). The Global Education Meeting. Retrieved February 23, 2019, from https://en.unesco.org/events/globaleducation-meeting

24. United Nations (2011, December). Disability and the Millennium Development Goals. Retrieved February 5, 2019, from http://www.un.org/ disabilities/documents/review_of_disability and the mdgs.pdf

25. United Nations (2015, July). Convention on the Rights of Persons with Disabilities: Improvement of Disability Data and Statistics: Objectives and Challenges. Retrieved February 5, 2019, from http://www.un.org/disabilities/documents/COP/ cosp8_report_e.pdf

26. VDEĀ VK (2013, November). Rokasgrāmata personas veselības, funkcionālo spēju un vispārējo darbspēju novērtēšanai (Guidelines for the Evaluation of a Person's Health, Functional Capacity and General Working Capacities). Retrieved February 23, 2019, from http://www.vdeavk.gov.lv/wp- content/ uploads/2014/11/2013_Rokasgramata_FINAL. docx (In Latvian)

27. VISC (2010, December). Asistenta personām ar dzirdes traucējumiem profesijas standarts (The Standard of Profession of an Assistant for People with Hearing Disorders). Retrieved March 1, 2019, from https://visc.gov.lv/profizglitiba/ dokumenti/standarti/ps0461.pdf ( In Latvian)

28. VISC (2017, March). Individuālā pieeja katram skolēnam vispārējās izglītības iestādēs (Individual Approach to Every Student in General Education Institutions). Retrieved February 2, 2019, from https://www.tip.edu.lv/ media/files/Ieteikumi_versija_14032017.pdf (In Latvian)

29. Voitkane, V. (2017). Inclusive Education in Italy. Proceedings of the International Scientific Conference "SOCIETY, INTEGRATION, EDUCATION - SIE2017, Volume III, p.136 146, 26-27 May 2017. Rēzekne: Rēzeknes Tehnoloǵiju akadēmija. DOI: http://dx.doi. org/10.17770/sie2017vol3.2281 Retrieved
November 13, 2018, from http://journals.ru.lv/ index.php/SIE/article/view/729/843

30. Waddington, L., \& Diller, M. (2002). The Uneasy Relationship Between Social Welfare and Civil Rights Models of Disability in American, European and International Employment Law. Retrieved November 2, 2018, from https://dredf. org/news/publications/disability-rights-law-andpolicy/tensions-and-coherence-in-disabilitypolicy/

31. Архипова, Е. Ф. (2017). Инклюзивное образование детей с нарушением опорнодвигательного аппарата (Inclusive Education for Children with Locomotor Apparatus Impairment). Особый ребёнок, с. 34 - 39. Retrieved November 2, 2018, from https:// cyberleninka.ru/article/n/inklyuzivnoeobrazovanie-detey-s-narusheniem-opornodvigatelnogo-apparata (In Russian)

32. Виды нарушений зрения у детей (Types of vision disorders in children) (2016, January). Retrieved November 2, 2018, from https:// proglaza.ru/articles-menu/vidy-narusheniyzreniya-u-detey.html (In Russian)

33. Казанцева, В. А., \& Биляченко, М. А.(2017). Инклюзивное образование как потребность современного общества (Inclusive Education as a Need of Modern Society). Научнометодический электронный журнал Кониепт, Т.38, с. 23-27. Retrieved November 2, 2018, from https://e-koncept.ru/2017/T38. htm (In Russian)

34. Особенностиобученияребенкаснарушениями опорно-двигательного аппарата 6 общеобразовательном учреждении (Specific Features or Learning for a Child with Muscleskeleton Disorders in a General Education Setting) (2012). Москва; Санкт-Петербург: Нестор-история (In Russian)

35. Пашкова, М.Н.,\& Скуднова, Т.Д. (2018). Инклюзивное образование в Испании (Inclusive Education in Spain). Москва; Берлин: Директ - Медиа. (In Russian)

36. Староверова, М., Ковалев, Е.,\& Захарова, А. (2018). Инклюзивное образование. Настольная книга педагога, работающего c детьми с ОВЗ. Методическое пособие. (Inclusive Education. A Handbook for Teachers Working with Children with Health Limitations. Teacher Edition). Москва: Владос. (In Russian) 